\title{
Book Review: Andreas Pickel, The Problem of Order in the Global Age
}

\section{Christian Fuchs}

Unified Theory of Information Research Group, University of Salzburg, http://www.uti.at, http://fuchs.uti.at, christian.fuchs@sbg.ac.at

Pickel, Andreas. 2006. The problem of order in the global age: systems and mechanisms. New York: Palgrave Macmillan. ISBN: 978-1-4039-7244-6, ISBN10: 1-4039-7244-3

$51 / 2 \times 81 / 4$ inches, 224 pages. 80 \$US.

Keywords: Andreas Pickel, order, global age, globalization, systemism, systems, mechanisms, nationalizing

\section{Introduction}

th he task of Andreas Pickel's book is to theoretically explain how order is possible and changes and to relate this discussion to contemporary societies and transformations. In the first part of the book, the tools employed for achieving this goal are introduced: systemism, mechanism, and the problem-oriented approach. In the second and third part, these tools are applied for analyzing postcommunist transformations and globalization processes.

Pickel's theory is grounded in Mario Bunge's philosophy and aims at overcoming the structure-agency divide in social theory. This is an important aim that this approach shares for example with Jean-Paul Sartre's concept of dialectical reason, Roy Bhaskar's transformational model of social activity, or Anthony Giddens' structuration theory. Such concepts have in common that they are dialectically approaching the subject-object problem of social theory. Systemism is an ontology that questions holism and individualism. It focuses not like Luhmann's or Parsons' concepts of systems primarily on structures and functions, but on structures and actors as well as on mechanisms that relate these two levels. It contributes to the establishment of less fragmented, more integrated, and more unified social theories. Pickel distinguishes between material, semiotic, and conceptual systems.
Andreas Pickel sees Popper's method of criticism not only as suited for testing and improving knowledge, but also as method for questioning norms, politics, society, and ideologies. This interpretation of Popper opens up parallels and possible connections to approaches of ideology critique that at the time of the Positivism dispute in German sociology in the early 1960s were not possible and not visible in the debates between Popper, Adorno, and others. Pickel applies Popper's method to the latter's concept of sovereignty in order to show with the help of Bodin, Hobbes, and Locke the untenability of the assumption that the focus of sovereignty theory should be on the balance of power instead of on the discussion of the legitimacy of the rule of certain groups.

Pickel introduces three levels for the analysis of postcommunist transformations: theory, strategy, and ideology. He discusses at these three levels the differences between the neoclassical-radical-neoliberal approach and the evolutionary-gradualist-socialdemocratic position. He shows that Popper's criticism of utopian social engineering can be applied to neoliberalism. He argues that neoliberalism is a pseudo-scientific doctrine that lacks a theory of society and social change so that in political reality the resulting political doctrine of individualism has created social inequalities. Pickel suggests at the scientific level as contrast a unified social science and 
cross-disciplinary analyses. He advances the notion of catalytic design as policy perspective that combines aspects of intervention and spontaneity and focuses on guiding and triggering changes. It could be an interesting task to work out differences and commonalities between the catalytic design concept and Helmut Willke's (1995) notion of decentral context steering.

In globalization studies, scholars such as Kenichi Ohmae have argued that as a result of contemporary globalization processes "the modern nation state itself [...] has begun to crumble" and that "nation states have become little more than bit actors" (Ohmae $1995,7,12)$. It is this background that structures Pickel's engagement with the notion of globalization. He questions the assumption that globalization causes a serious decline of the national by working out concepts such as homo nationis (the psychosocial foundation of the nation state), the national habitus, and nationalizing mechanisms. Concepts such as homo faber, homo ludens, homo rationabilis, or zoon politikon convey the impression that there is a certain human essence and therefore an anthropological constancy of man. Therefore some people may understand the term homo nationis as meaning nation building as anthropological quality, although Pickel stresses the historicity (pp. 88, 141) and imaginary character (p. 137) of the nation. This shows the importance of distinguishing between essence and actual being in social theory.

Andreas Pickel uses the concepts of the state, the nation, subordinate nations, economic systems, cultural systems, and political systems in order to provide a model of society that he uses for the discussion of nationalizing mechanisms. He provides an interesting framework for social theory that distinguishes five levels of analysis (individual, local, state-society, regional, global) and four system types (economic, political, cultural, biosocial). If we assume that information and communication technologies have a certain importance in contemporary society, then the question arises how technological systems and the media fit into this model that distinguishes four kinds of systems.

Pickel argues that nationalizing mechanisms interact with processes at all five levels of analysis. At each level, nationalizing mechanisms interact with all system types. Andreas Pickel convincingly shows that the system-action dialectic that is constitutive for systemism shapes these interaction processes. Roland Robertson (1992) has argued that globalization and localization processes are connected. Pickel shows that globalization and nationalizing mechanisms are linked and thereby provides a theoretical framework for deconstructing strong globalization hypotheses or what David Held and Anthony McGrew (2007) have termed the globalist analysis.

There is a difference between claiming that nationalizing mechanisms are of centrality/primacy in contemporary society (pp. 16, $77,145,154,159)$ and saying that they are important and significant (pp. 157, 159, 167). The author remains rather unclear on this point. The new global economic crisis has shown the importance of class, capital, and labour in contemporary society, which questions the assumption of the centrality of nationalizing mechanisms and speaks for the more modest claim that stresses the importance and significance of nationalizing mechanisms.

Andreas Pickel's approach can best be characterized as realist, materialist, emergentist, and dialectical. His book is an important contribution for establishing alternative systems conceptions that question and challenge the Luhmann hegemony in systems thinking. Besides that it is a powerful and valuable input and impulse for all those who are interested in social theory, political theory, economic theory, and cultural theory or want to better understand contemporary globalization. 


\section{References}

Held, D. \& McGrew, A. (2007) Globalization/Anti-Globalization. Cambridge: Polity. $2^{\text {nd }}$ edition. Ohmae, K. (1995). The End of the Nation State. New York: Free Press.

Robertson, R. (1992). Globalization. Social Thoery and Global Culture. London: Sage.

Willke, H. (1995). Systemtheorie III: Steuerungstheorie. Stuttgart: Fischer.

\section{About the Author}

Christian Fuchs

Christian Fuchs holds a venia docendi from the University of Salzburg in the field information and communication technologies \& society. His areas of research are: social theory, critical theory, information society studies, media \& society, ICTs \& society. He is author of more than 110 academic publications, among them the book Internet and Society: Social Theory in the Information Age (New York: Routledge 2008) and the study Social Networking Sites and the Surveillance Society. A Critical Case Study of the Usage of studiVZ, Facebook, and MySpace by Students in Salzburg in the Context of Electronic Surveillance (Vienna 2009). 